\title{
Physical Interactions among Human Glycosyltransferases Involved in Dolichol-Linked Oligosaccharide Biosynthesis
}

\section{ドリコール中間体生合成に関与するヒト糖転移酵素間の物理的相互作用}

\author{
Takahashi, Tetsuo ${ }^{1}$; and Gao, Xiao-Dong ${ }^{2}$ \\ ${ }^{1}$ Department of Applied Biochemistry, School of Engineering, Tokai University, Hiratsuka, Kanagawa 259-1292, Japan \\ ${ }^{2}$ The Key Laboratory of Carbohydrate Chemistry and Biotechnology, Ministry of Education School of Biotechnology, \\ Jiangnag University, Wuxi, Jiangsu Province 214122, China \\ FAX: 81-463-50-2506, E-mail: tetsuo@keyaki.cc.u-tokai.ac.jp
}

(Received on February 3, 2012, accepted on February 13,2012)

Key Words: glycosyltransferase, dolichol-linked oligosaccharide, physical interaction, split-ubiquitin system

\begin{abstract}
In eukaryotic glycoproteins, the $N$-glycan plays an important role with respect to both their structure and function. On the rough endoplasmic reticulum (rER) membrane, the $\mathrm{N}$-glycan precursor is biosynthesized as a dolichol-linked oligosaccharide (DLO), which consists of fourteen sugars linked to pyrophosphoryl- dolichol. For completion of fulllength DLO $\left(\mathrm{Glc}_{3} \mathrm{Man}_{9} \mathrm{GlcNAc}_{2}\right.$-PP-dolichol), activities of at least eleven glycosyltransferases localized on the rER membrane are essential. Although twelve human genes for these enzymes have been identified, any physical interactions among them have not yet been systematically analyzed. In this review, we describe several physical interactions among them that were uncovered using the yeast split-ubiquitin system. Moreover, on the basis of observations obtained by this technique, novel models for networking among human glycosyltransferases can be proposed.
\end{abstract}

要 約

真核細胞が有する糖タンパク質において、 $N$ - グリカン $(N-$ 結合型糖鎖) は、構造と機能の両面に関して重要な役割を果 たしている。N-グリカンの前駆体は、粗面小胞体 (rER) 膜上 において、ドリコールピロリン酸に結合した 14 糖からなる ドリコール中間体 (DLO) として生合成されている。完全長の DLO(Glc $\mathrm{Man}_{9} \mathrm{GlcNAc}_{2}$-PP-ドリコール)の完成には、rER 膜 に局在する少なくとも 11 種類の糖転移酵素の活性が必要不可 欠である。これらの酵素に関する 12 種類のヒト遺伝子は既に 同定されてはいるものの、酵素間の物理的相互作用は、未だ に体系的に解析されてはいない。そこで本稿では、これら酵 素間に打ける幾つかの物理的相互作用を述べる。それらは酵 母 split-ubiquitin システムを用いることにより明らかにされた ものである。さらに、この技法により得られた観察結果に基 づくと、ヒト糖転移酵素間のネットワーク形成に関する新た なモデルが提案可能である。

\section{A. Introduction}

In eukaryotic cells, the $\mathrm{N}$-glycans on glycoproteins play a critical role in their structure and function, influencing various biological phenomena. The $N$-glycan precursor, dolichol-linked oligosaccharide (DLO), is comprised of fourteen sugars that are linked to dolichol via pyrophosphate. The biosynthesis of DLO is an essential process to normal and adaptive behavior of eukaryotic cells, where each monosaccharide is sequentially added to dolichol-phosphate by eleven glycosyltransferases localized on the rough endoplasmic reticulum (rER) membrane. In humans, various deficiencies in this process cause congenital disorder of glycosylation type I (CDG-I), where the number of N-glycans per $N$-glycoprotein is diminished $(1,2)$.

As shown in Fig. 1, early assembly of half-length DLO ( $\mathrm{Man}_{5} \mathrm{GlcNAc}_{2}$-PP-dolichol) on the cytosolic side of the rER membrane involves one $\mathrm{N}$-acetylglucosamine

\section{A. はじめに}

真核細胞では、糖タンパク質上の $N$-グリカンが、糖タン パク質の構造及び機能ひいては様々な生命現象に重要な役割 を果たしている。この $N$-グリカンの前駆物質であるドリコー ル中間体 (DLO) は、ドリコールに対してピロリン酸を介して 結合した 14 の単糖から構成されている。DLO の生合成は、粗 面小胞体 $(\mathrm{rER})$ 膜上に局在している 11 種類の糖転移酵素によっ てドリコールリン酸に対して各単糖が連続的に付加されてい く、真核細胞の通常及び適応的な挙動にとって必須な過程で ある。ヒトに扔いてこの過程における様々な不全は、 $\mathrm{N}$ - 結合 型糖タンパク質あたりの $N$-グリカンの数が減少してしまう先 天性グリコシル化異常症 I 型 (CDG-I) を引き起こす $(1 、 2)$ 。

図1に示す通り、rER 膜の細胞質側での半分長 DLO( $\mathrm{Man}_{5} \mathrm{GlcNAc}_{2}$-PP-ドリコール)の前期集合には、1 種類 の N-アセチルグルコサミン -1-P 転移酵素 (GPT)、Alg13p と 


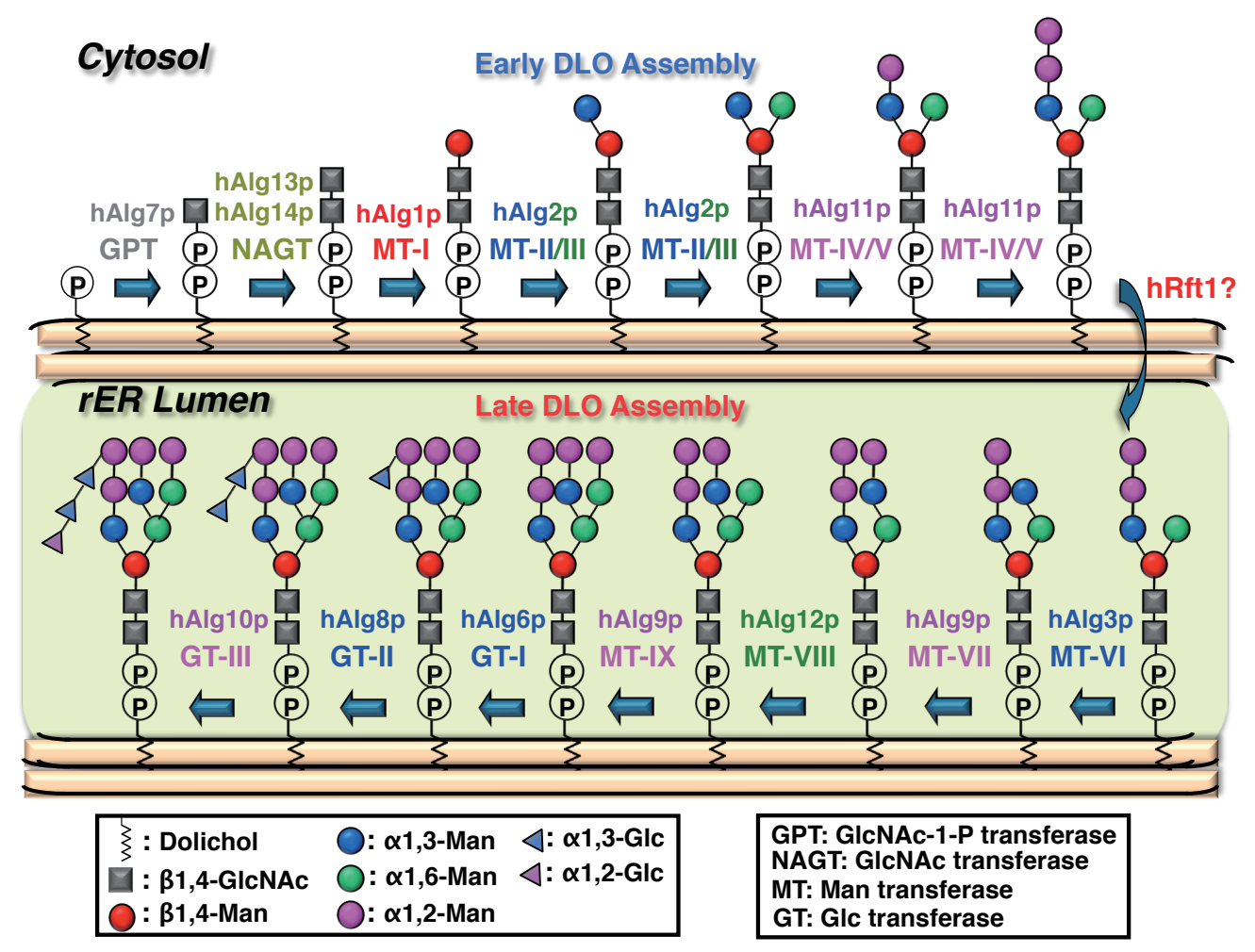

Fig. 1. The biosynthetic pathway of dolichol-linked oligosaccharide (DLO) on the rough endoplasmic reticulum (rER) membrane in human cells. The first seven steps of DLO biosynthesis are carried out on the cytoplasmic side of the rER membrane. This early DLO assembly involves five glycosyltransferase activities from UDP-GlcNAc and GDP-Man donors to dolichol-phosphate acceptors, including GPT (hAlg7p), NAGT (hAlg13p/hAlg14p complex), and three MTs (hAlg1p, hAlg2p, and hAlg11p). The half-completed DLO assembled on the cytosolic side is then translocated (flipped) to the luminal side of the rER membrane by a putative flippase (hRft1?). The last seven steps of DLO biosynthesis are conducted by three MTs (hAlg3p, hAlg9p, and hAlg12p) and three GTs (hAlg6p, hAlg8p, and hAlg10p) that catalyze the transfer of mannosyl and glucosyl residues from dolichol-P-Man and dolichol-P-Glc donors, respectively.

phosphotransferase (GPT), one $N$-acetylglucosaminyltransferase (NAGT) consisting of Alg13p and Alg14p, and three mannosyltransferases (MT-I, MT-II/III, and MT-IV/V). Then this DLO is translocated from the cytosolic side to the ER luminal side by a putative flippase including the Rft1 protein. Finally, full-length DLO $\left(\mathrm{Glc}_{3} \mathrm{Man}_{9} \mathrm{GlcNAc}_{2}-\mathrm{PP}\right.$-dolichol) is assembled by three mannosyltransferases (MT-VI, MT-VII/IX, and MT-VIII) and three glucosyltransferases (GT-I, GT-II, and GT-III) on the luminal side of the rER membrane.

Although the human glycosyltransferases mentioned above are all localized on the rER membrane and are considered to coordinately act with each other in order to build up DLO, a comprehensive analysis of the physical interactions among them remains to be reported. Thus, we clarified the possible glycosyltransferase network on the rER membrane by investigating their physical interactions using the yeast splitubiquitin system, a kind of yeast two-hybrid technique (3).

\section{B. The Yeast Split-Ubiquitin System}

For a series of cooperative reactions by several glycosyltransferases in an ordered manner, it is thought that there might be transient and/or stable interactions among
$\mathrm{A} \lg 14 \mathrm{p}$ から構成される 1 種類の $N$ - アセチルグルコサミン転 移酵素 (NAGT) 及び 3 種類のマンノース転移酵素 (MT-I、MTII/III 及びMT-IV/V) が関連している。次に、この DLO は、 Rft1 タンパク質を含む仮想的フリッパーゼにより細胞質側か ら ER 内腔側に転送される。最終的に、完全長 DLO $\left(\mathrm{Glc}_{3} \mathrm{Man}_{9}\right.$ $\mathrm{GlcNAc}_{2}$-PP-ドリコール) が、rER 膜の内腔側で 3 種類のマン ノース転移酵素 (MT-VI、MT-VII/IX 及び MT-VIII) と 3 種類 のグルコース転移酵素 (GT-I、GT-II 及び GT-III) により集合する。

上記のヒト糖転移酵素はいずれも rER 膜に局在する膜 タンパク質であり、DLOを作りあげるために互いに協調し て働いているものと考えられているものの、酵素間の物理的 相互作用に関する包括的な解析は、これまで報告されていな かった。そこで私たちは、酵母ッーハイブリッド技法の1種 である酵母 split-ubiquitin システム (3) を利用して、 $N$ - グリカ ン (DLO) 生合成に関連する rER 膜局在ヒト糖転移酵素間の相 互作用を調査することにより、これらの酵素間で考えられる rER 膜上でのネットワークを明らかにした。

B. 酵母 split-ubiquitin システム

幾つかの糖転移酵素による秩序だった一連の協調的な反 応には、それらの間に一過的あるいは安定的な相互作用が存 在している可能性が考えられる。膜結合した糖転移酵素間の 
them. In order to sensitively detect possible interactions among membrane-associated glycosyltransferases in vivo, we applied the yeast split-ubiquitin system, a powerful technology that was specially devised for the detection of physical interactions between two membrane proteins (4-6). Using this methodology, various physical interactions among membrane proteins, including enzymes or subunits of an enzymatic complex residing on the rER membrane, have been revealed ( 7 $-10)$.

\section{B-1. Principal for Detection of Physical Interactions between Two Membrane Proteins}

In the system, one membrane protein of interest is fused with the Cub-LexA/VP16 (Cub-LV) cassette, the C-terminal half of ubiquitin followed by transcriptional activators LexA and VP16, and expressed in yeast host cells, as seen in Fig. 2. For tagging of the Cub-LV cassette, pBT-N or pBT-STE expression vectors are used to prepare bait constructs (see below). Another membrane protein of interest is fused with $\mathrm{Nub}$, the N-terminal half of ubiquitin, and used as a prey that is co-expressed with the bait in the same cell (Fig. 2).

If the Cub-LV cassette fused to the bait is co-expressed with NubI, a wild-type Nub, of the positive control prey (pAIAlg5) together in the cytoplasmic side of the rER membrane, Cub and NubI spontaneously associate with each other, thereby forming split-ubiquitin, which in turn is recognized by ubiquitin-specific proteases (UBPs) present in the cytosol. As a result, the LV portion is cleaved from the bait to automatically in Vivoに打ける潜在的な相互作用を鋭敏に検出するために私 たちは、酵母 split-ubiquitin システムを適用した。このシステ ムは 2 つの膜タンパク質間の物理的相互作用を検出するため に特別に考案された強力な技術である(4-6)。この方法を利用 して、rER膜に局在する酵素または酵素複合体のサブユニッ 卜を含む膜タンパク質間の様々な物理的相互作用が、今まで に明らかにされている (7-10)。

\section{B-1. 2 つの膜タンパク質間の物理的相互作用を検出する原理}

図 2 に見られるように、このシステムに㧍いて、対象とな る膜タンパク質の 1 つは、ユビキチンのC 末端側半分に転写 活性化因子 LexA 及び VP16 を連結したCub-LexA/VP16(CubLV) カセットと融合したうえで宿主の酵母細胞で発現される。 Cub-LV カセットのタグ付加には、pBT-N 及び pBT-STE 発現 ベクターが利用され、ベイトコンストラクトが調製される(以 下参照)。もう１つの対象となる膜タンパク質は、ユビキチン の N- 末端半分である Nub と融合して、同一細胞中でべイトと 共に発現されるプレイとして使用される(図 2)。

仮にrER 膜の細胞質側でベイトに融合したCub-LVカ セットを、陽性コントロールプレイ pAI-Alg5 中の NubI( 野生 型 Nub) とともに共発現すると、Cub と NubI は自発的に互い と会合し、それによって split-ubiquitin が形成される。形成さ れた split-ubiquitin は、細胞質に存在するユビキチン特異的プ ロテアーゼ群 (UBPs) により認識され、その結果、LVの部分 はベイトから切断された後に自動的に核に移行して、2つのレ

Fig. 2. The yeast split-ubiquitin system. In this system, the yeast ubiquitin gene is artificially split into two segments, one of which codes for the $\mathrm{N}$-terminal half of ubiquitin (Nub), and the other for the C-terminal half of ubiquitin (Cub). NubI (wild-type Nub) and Cub can spontaneously form split-ubiquitin in vivo, whereas NubG (mutant Nub) and Cub cannot. However, if NubG is forced to position near $\mathrm{Cub}$, they can associate into splitubiquitin. In the yeast host cells of the NMY51 strain, bait membrane protein terminally fused with Cub-LexA/VP16 (Cub-LV) is co-expressed with the prey membrane protein terminally fused with NubG. If the bait does not physically interact with a prey such as pDL-Alg5, a negative control prey prepared in this system (left side in the figure), the two reporter genes are not activated because the transcription factor LexA/VP16 (LV) portion of the bait remains to be anchored to the membrane. Conversely, if the bait interacts with the prey (center in the figure), wild-type Cub and mutant NubG can be made into a split-ubiquitin,

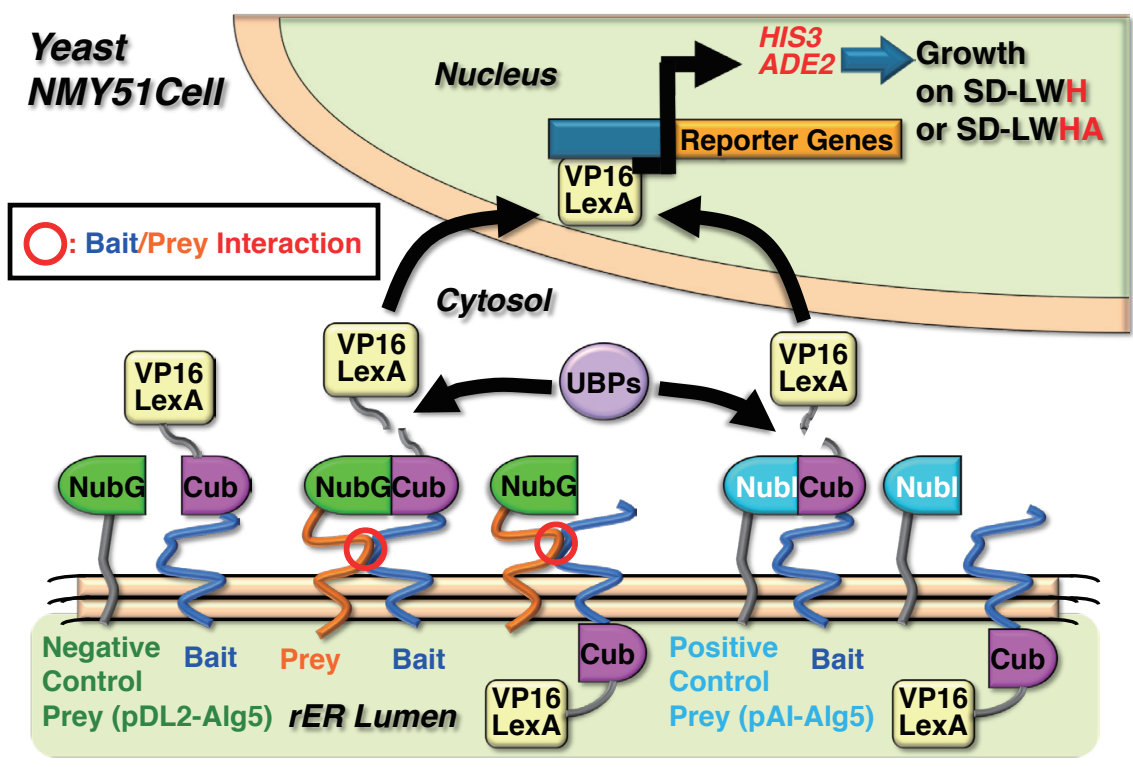
which is in turn recognized by ubiquitin-specific proteases (UBPs), and the LV portion is released from the bait. Free LV translocates to the nucleus and consequently induces HIS3 and ADE2 expression. However, for this reporter activation, both Cub-LV and NubG portions must be co-expressed on the cytosolic side because UBPs act only in the cytosol (center in the figure). To ascertain whether the Cub-LV portion of the bait is positioned on the cytosolic side, the bait fusion is first co-expressed with pAI-Alg5, a positive control prey prepared in this system. As NubI in pAI-Alg5 can spontaneously associate with Cub without interaction between bait and prey to form split-ubiquitin, only if Cub-LV is expressed in the cytosol, reporters become activated, whereas if it is expressed in the ER lumen, they do not (right side in the figure). 
translocate into the nucleus and then transactivate two reporters, HIS3 and $A D E 2$ (right side in Fig. 2). Expression of the reporters is detectable by growth examination of cotransformants with bait and prey on synthetic dextrose (SD) minimum medium lacking histidine and adenine (upper in Fig. 2).

In contrast, if the Cub-LV cassette fused to the bait is co-expressed with NubG, a mutant Nub, of the negative control prey (pDL2-Alg5) together in the cytoplasmic side of the rER membrane, Cub and NubG are not able to spontaneously associate with each other, consequently resulting in non-expression of the reporters (left side in Fig. 2).

However, only if the prey itself physically interacts with the bait so that NubG fused to the prey is positioned near Cub fused to the bait, both can complex into split-ubiquitin, leading to reporter expression (center in Fig. 2). For NubG tagging, pPR-N and pPR-STE expression vectors are available to prepare prey constructs (see below). On the basis of reconstitution of split-ubiquitin dependent on the bait-prey interaction and subsequent activation of reporter genes, the yeast split-ubiquitin system detects interactions between two membrane proteins in vivo.

\section{B-2. Experimental Procedures}

At the beginning of analyses with the yeast splitubiquitin system, bait constructs were prepared by cloning each human glycosyltransferase gene, described in Fig. 1, into pBT-N and pBT-STE vectors. The pBT-N and pBT-STE vectors are designed for expression of bait proteins, which are $\mathrm{N}$ - and $\mathrm{C}$ - terminally fused with the Cub-LV cassette, respectively.

Next, to test whether the Cub-LV portion of the bait protein expressed in yeast cells is present in the cytosol, a bait construct was co-expressed with pAI-Alg5, a positive control prey prepared in this system. As NubI in pAI-Alg5 is located in the cytosol and can spontaneously associate with Cub without interactions between the bait and prey to form split-ubiquitin, if Cub-LV of the bait is expressed in the cytosol, reporters in the yeast cell are activated, whereas if it is expressed in the ER lumen, they are not (right side in Fig. 2).

These membrane topological assays of bait termini allow us to select bait and prey constructs available for further analyses of physical interactions with the yeast split-ubiquitin system. Prey constructs were prepared by subcloning each gene from bait constructs to prey vectors, $\mathrm{pPR}-\mathrm{N}$ and/or $\mathrm{pPR}$ STE. The pPR-N and pPR-STE vectors are designed for expression of prey proteins, which are $\mathrm{N}$ - and C- terminally fused with NubG, respectively.

Out of the bait and prey constructs obtained though the process mentioned above, any two (bait and prey) were chosen, and the NMY51 strain, a yeast host cell harboring reporter genes, was co-transformed with their combination.
ポーター遺伝子 HIS3 及び ADE2 を転写活性化する ( 図 2 の右 側部分)。レポーター発現は、ヒスチジンとアデニンを欠如す る合成デキストロース (SD) 最少培地上でのベイト・プレイの 共発現株の増殖試験により検出可能である (図 2 の上部)。

対照的に、もし rER 膜の細胞質側でベイトに融合した Cub-LV カセットを、㓌性コントロールプレイ pDL2-Alg5 の NubG( 変異型 Nub) とともに共発現する場合は、Cubと NubG は自発的に互いと会合できないため、レポーターの発現は生 じない(図 2 の左側部分)。

しかしながら、プレイ自身がベイトと物理的に相互作用 して、その結果、プレイに融合したNubGがベイトに融合し たCubの近傍に配置される場合に限り、両者はsplit-ubiquitin へと複合体形成してレポーター発現を誘導可能である (図 2 の 中央部分 )。NubG タグ付加には pPR-N 及び pPR-STE 発現べ クターが利用可能であり、プレイコンストラクトが調製され る (以下参照)。このベイト・プレイ間の相互作用に依存した split-ubiquitinの再構成とその後に生じるレポーター遺伝子の 活性化に基づいて、酵母 split-ubiquitin システムは、2つの膜 タンパク質間の物理的相互作用を in Vivo で検出している。

\section{B-2. 実験の手順}

まず酵母 split-ubiquitin システムによる解析を開始するに あたり、図 1 に記載された各ヒト糖転移酵素遺伝子を 2 種の ベクター (pBT3-N 及び pBT3-STE) ヘクローニングすること によってベイトコンストラクトを調製した。なお pBT3-Nベ クターはN-末端に、pBT3-STEベクターはC- 末端に、Cub$\mathrm{LV}$ カセットを融合したベイトタンパク質を発現するためにそ れぞれ設計されている。

次に、酵母細胞内で発現しているべイトタンパク質の Cub-LV 部分が細胞質内に存在しているかどうか調べるため、 ベイトコンストラクトをこのシステムで用意されている陽性 コントロールプレイ pAI-Alg5 と共発現させた。pAI-Alg5 中 のNubIは細胞質中に位置し、ベイト・プレイ間の相互作用 が無い状態でも自発的にCub と結合して split-ubiquitin を形 成できるので、もしべイト中の Cub が細胞質で発現するなら ば酵母細胞内のレポーターは活性化される。一方、それが $\mathrm{ER}$ 内腔で発現するならば、レポーターは活性化されない (図 2 の 右側部分)。

ベイト末端についてのこの膜配向性の試験により、酵母 split-ubiquitin システムを用いた物理的相互作用に関するその 後の解析に利用可能なべイトコンストラクト及びプレイコン ストラクトを選択することが可能になっている。プレイコン ストラクトは、ベイトコンストラクトからプレイベクターで ある pPR-N または pPR-STEへのサブクローニングによって 調製された。pPR-N 及び pPR-STEベクターは、それぞれ N末端及びC- 末端にNubG を融合したプレイタンパク質を発現 するために設計されている。

上記の過程を通して取得されベイトコンストラクト及び プレイコンストラクトから、任意の $2 つ$ (ベイトとプレイ)を 選び、それらの組み合わせを用いて、レポーター遺伝子を内 
Via selection on SD medium lacking leucine and tryptophan (SD-LW), co-transformants that expressed both bait and prey were isolated and then subjected to growth examination on SD medium lacking histidine (SD-LWH) and histidine/ adenine (SD-LWHA), in addition to leucine/tryptophan, for investigating reporter expression and therefore the existence of physical interactions between bait and prey membrane proteins. Growth of co-transformants on both SD-LWH and SD-LWHA selective media indicates that a stronger interaction between bait and prey membrane proteins occurs in the host cell, while growth on only SD-LWH medium due to poor reporter expression means a weaker interaction between them.

\section{Human Glycosyltransferases Involved in Early DLO Assembly}

In humans, GPT, NAGT, and three MTs are involved in the early biosynthesis of half-sized DLO (Man5GlcNAc2-PPdolichol) on the cytosolic side of the rER membrane, similar to yeast. These glycosyltransferases are polytopic enzymes and possess catalytic domains facing toward the cytoplasm, because they utilize nucleotide sugars present in the cytoplasm as donor substrates (UDP-GlcNAc for GPT and NAGT, and GDP-Man for MTs).

As a consequence of analyzing membrane topology, the C-termini of five enzyme baits were shown to all be localized in the cytosol (note that the co-transformant of each bait with the positive control prey pAI-Alg5 could grow on both SDLWH and SD-LWHA media as shown in Fig. 3A). These results agreed well with the membrane topological features that had previously been demonstrated for hamster (11) and yeast (12-14) enzymes. Therefore, for these enzymes, pBTSTE-based bait constructs were used for subsequent analyses of physical interactions with prey constructs (Fig. 3A; in the case of NAGT, the transmembrane subunit hAlg14p was used as bait, while the cytosolic subunit hAlg $13 p$ was not used because it could not anchor the Cub-LV portion toward the ER membrane).

\section{C-1. hAlg7p, hAlg14p, and hAlg13p Form a GPT/NAGT Complex}

When $\mathrm{hAlg} 7 \mathrm{p}$ was used as a bait, a co-transformant with hAlg7p prey grew on SD-LWH and SD-LWHA media (Fig. 3A), indicating that hAlg7p interacts with itself to form a dimer (or oligomer). This observation coincided with a previous report on hamster GPT (15). Co-transformants with hAlg14 prey also grew on both selective media (Fig. 3A). This interaction between $\mathrm{hAlg} 7 \mathrm{p}$ and $\mathrm{hAlg} 14 \mathrm{p}$ was again detected when hAlg $14 \mathrm{p}$ was used as bait (Fig. 3A), strongly supporting previous findings that $\mathrm{Alg} 7 \mathrm{p}$ associates with $\mathrm{Alg} 14 \mathrm{p}$ to form a hetero-oligomeric GPT/NAGT complex on the rER membrane in Saccharomyces cerevisiae, demonstrated with in vitro co-immunoprecipitation assays (16). Furthermore,
在する酵母宿主細胞であるNMY51 株を二重形質転換した。 ロイシンとトリプトファンを欠如する SD 培地 (SD-LW) 上で の選択を経てベイトとプレイの両方を発現する二重形質転換 株が単離され、次にそれらは、レポーター発現とそれによる ベイト・プレイ膜タンパク質間の物理的相互作用の存在を調 査するために、ロイシンとトリプトファンに加えて、ヒスチ ジンを欠如する SD 培地 (SD-LWH) やヒスチジンとアデニンを 欠如する SD 培地 (SD-LWHA) 上での増殖試験にかけられた。 SD-LWH 及びSD-LWHA の両選択培地での二重形質転換株の 増殖は、宿主細胞内でベイト・プレイ膜タンパク質間に比較 的強い相互作用が生じたことを示し、一方、レポーター発現 が少ないことによる SD-LWH 培地のみの増殖は、それらの間 に比較的弱い相互作用が生じたことを意味することになる。

\section{C. 前期 DLO 生合成に働く糖転移酵素}

酵母と同様に、ヒトに扮いてGPT、NAGT 及び 3 種 類のMTが、rER膜の細胞質側に扔ける半分サイズの DLO( $\mathrm{Man}_{5} \mathrm{GlcNAc}_{2} \mathrm{PP}$ - ドリコール) の前期生合成に関連して いる。これらの糖転移酵素はポリトピック型酵素であり、供 与体基質として細胞質に存在する糖ヌクレオチドを利用して いるため(GPT と NAGT は UDP-GlcNAcを、3 種類の MT は GDP-Man を利用)、細胞質に向いた触媒ドメインを有している。

膜配向性に関する解析を行った結果、5 種類の酵素べイ トのC- 末端は、すべて細胞質に局在化していることが示され た(図3Aに示した通り、各ベイトの陽性コントロールプレイ である pAI-Alg5 との二重形質転換株が、SD-LWH 及び SDLWHA 培地の両方で増殖可能であったことに注目)。これら の結果は、ハムスター (11) 及び酵母 (12-14) の酵素に関して以 前に実証されている膜配向性の特徵と良く符合していた。そ れ故に、これらの酵素に関して、pBT-STEに基づいたべイト コンストラクトが続いてのプレイコンストラクトとの物理的 相互作用の解析に使用された (図 3A；ただし、NAGT の場合、 膜貫通サブユニットであるh Alp14 がベイトとして使用され、 細胞質サブユニットであるhAlg13p の方は、Cub-LV 部分が ER 膜に対して係留不可能であったため、使用されなかった)。

C -1. hAlg7p、hAlg14p 及び hAlg13p は GPT/NAGT 複合 体を形成する

hAlg7 をベイトとして使用した場合、hAlg7p プレイとの 二重形質転換株は、SD-LWH 及び SD-LWHA 培地で増殖した (図 3A)。このことは、hAlg7p が自身と会合して二量体(ある いは少量体)を形成していることを示している。さらにこの観 察結果は、ハムスターGPTに関する以前の報告結果と符合し ていた(15)。hAlg14p プレイとの二重形質転換株もまた、両選 択培地上で増殖した (図 3A)。hAlg7p と hAlg14p 間のこの相 互作用は、hAlg14p をべイトとして用いた場合にも再度検出 され(図 3A)、出芽酵母に拈いて Alg7p が Alg14p と会合して $\mathrm{rER}$ 膜上でへテロ少量体の GPT/NAGT 複合体を形成してい るという、in vitroでの免疫共沈降試験によって実証された以 前の研究結果 (16) を強く支持している。さらに、私たちも最近、 
Fig. 3. Analyses of physical interactions among glycosyltransferases involved in early (panel A) and late (panel B) assembly of DLO. Red and pink enclosures show strong and weak interactions, respectively. Combinations of each bait construct (pBT-x) with negative control prey (pDL2-Alg5), each prey construct (pPR-x), or positive control prey (pAI-Alg5), were introduced into yeast NMY51 cells harboring two reporter genes (HIS3 and ADE2). Co-transformant cells expressing both bait and prey proteins were selected on synthetic dextrose (SD) minimal medium lacking leucine and tryptophan (SD-LW), then transferred onto SD medium lacking leucine, tryptophan, histidine (SD-LWH), and to SD medium lacking leucine, tryptophan, histidine, and adenine (SDLWHA), and incubated at $30{ }^{\circ} \mathrm{C}$ for 3 days.
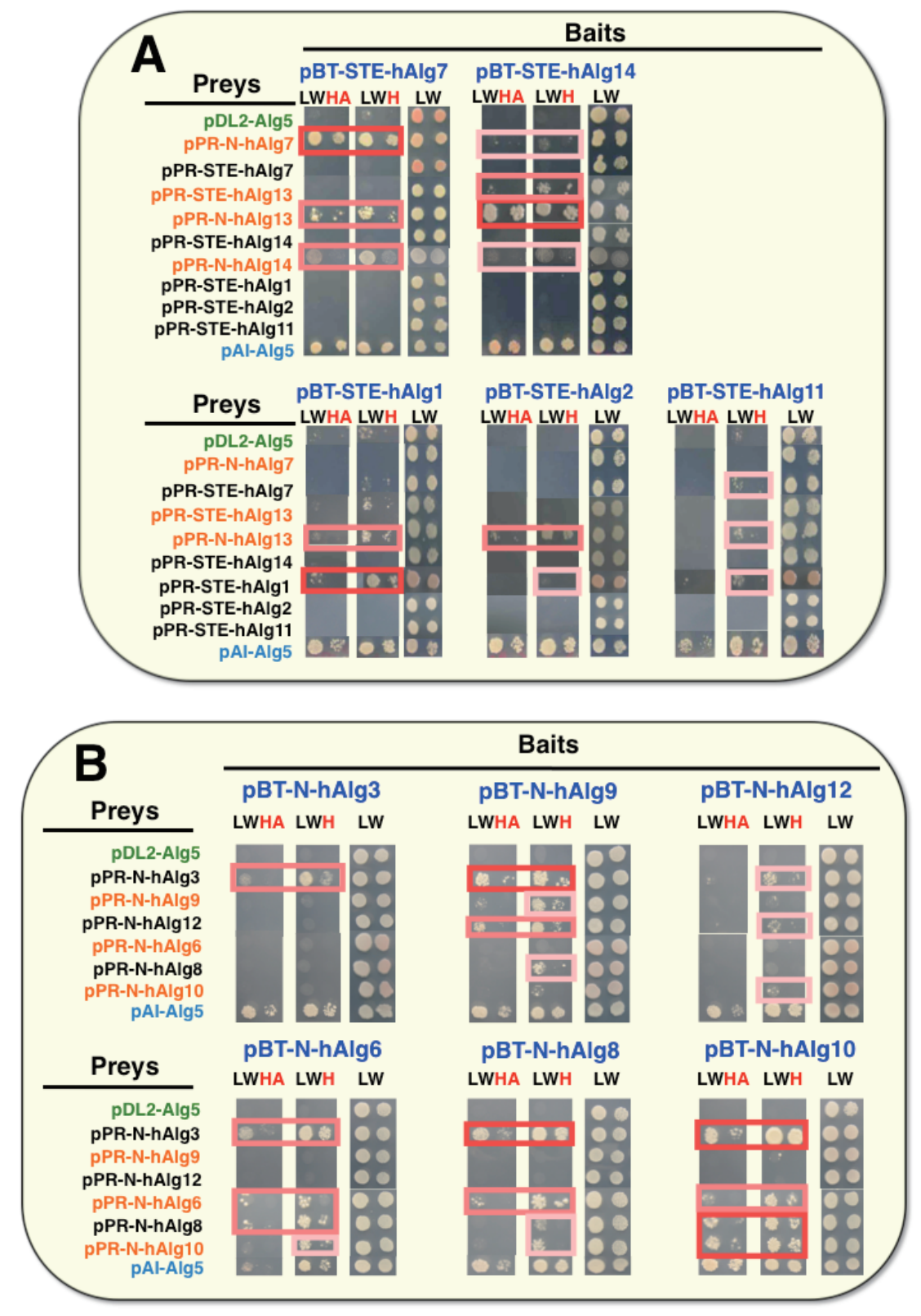

we also recently demonstrated that the $\mathrm{N}$-terminal domain of yeast $A \lg 14 p$ is essential for the formation of this enzymatic complex (17), strongly suggesting that the first two steps that initiate DLO synthesis are tightly coupled with each other, and that this process is highly conserved between yeast and humans.

The observation that co-transformants with two components of NAGT, hAlg14p bait and hAlg13p prey, strongly grew on both selective media (Fig. 3A) agrees well with previous reports in which it was demonstrated that they associate with each other with high affinity to form a tight complex, using co-immuno-precipitation assays by ourselves (18) and pull-down assays by another group (19).

\section{C-2. hAlg1p, hAlg2p, and hAlg11p Form a First MT Complex}


In analyses with three mannosyltransferases (hAlg1p, $\mathrm{hAlg} 2 \mathrm{p}$, and hAlg11p) involved in early DLO assembly as baits, each co-transformant with hAlg1p prey grew on SDLWH medium (Fig. 3A). Moreover, only co-transformants of $\mathrm{hAlg} 1 \mathrm{p}$ bait with $\mathrm{hAlg} 1 \mathrm{p}$ prey exhibited growth on SDLWHA medium (Fig. 3A), suggesting stronger interaction of hAlg1p with itself than with hAlg2p or hAlg11p. Furthermore, this observation is completely in accordance with physical interactions among yeast $\mathrm{Alg} 1 \mathrm{p}, \mathrm{Alg} 2 \mathrm{p}$, and $\mathrm{Alg} 11 \mathrm{p}$, which were detected with our co-immunoprecipitation experiments (20). Taken together, we found that these mannosyltransferases can associate with each other to form an MT complex that includes $h A l g 1 p, h A l g 2 p$, and hAlg11p in a ratio of $2: 1: 1$, respectively.

\section{C-3. Physical Interaction between the GT/NAGT Complex and the First MT Complex}

In the analyses described above, hAlg13p prey, a NAGT component, weakly and equally interacted with four enzyme baits (hAlg7p, hAlg1p, hAlg2p, and hAlg11p) aside from the hAlg14p bait, the original partner (Fig. 3A). These observations suggest that NAGT should physically interact with not only GPT but also the MT complex on the rER membrane. Interestingly, the hAlg11p bait, one enzyme in the MT complex, weakly interacted with hAlg7p prey (Fig. 3A), suggesting that GPT might also physically interact with the MT complex.

\section{Human Glycosyltransferases Involved in Late DLO Assembly}

In humans, three MTs and three GTs participate in late biosynthesis of full-sized DLO $\left(\mathrm{Glc}_{3} \mathrm{Man}_{9} \mathrm{GlcNAc}_{2}-\right.$ PP-dolichol) on the luminal side of the rER membrane, like in yeast. These glycosyltransferases are multi-spanning membrane proteins and face the catalytic domain toward rER lumen because they utilize dolichol-phosphate sugars present within the rER as donor substrates (dolichol-P-Man for MTs and dolichol-P-Glc for GTs).

As a result of our analysis of membrane topology, the $\mathrm{N}$-termini of six glycosyltransferase baits were shown to all be localized in the cytosol (note that co-transformants of each bait with positive control prey pAI-Alg5 could grow on both selective media as shown in Fig. 3B). These observations were coincident with a previous report of membrane topological predictions for these enzymes (21). Thus, for these enzymes, pBT-N-based bait constructs were used for further analyses of physical interactions (Fig. 3B).

\section{D-1. hAlg3p, hAlg9p, and hAlg12p Form a Second MT Complex}

When three mannosyltransferases (hAlg3p, hAlg9p, and hAlg12p) involved in late DLO assembly were used as baits, each co-transformant with hAlg3p prey grew on SD-
おいて、hAlg1p プレイとの各二重形質転換株は、SD-LWH 培 地上で増殖した (図 3A)。さらに、hAlglp ベイトの hAlglp プレイとの二重形質転換株のみは、SD-LWHA 培地上でも増 殖性を示した (図 3A)。この結果は、hAlglpの自身との相 互作用の方が h Alg2p または hAlg11p との相互作用よりも強 いことを示唆している。さらにこの観察結果は、以前私たち が免疫共沈降実験により検出した酵母の Alg1p、Alg2p 及び Alg11p 間の物理的相互作用 (20) とも完全に符合している。総 合すると、これらのマンノース転移酵素は互いに相互作用し て hAlg1p、hAlg2p 及びhAlg11p をそれぞれ 2:1:1 の割合で含 む MT 複合体を形成する可能性があることを私たちは見出し た。

\section{C -3. GT/NAGT 複合体と第 1 の MT 複合体の間の物理的相} 互作用

上記の解析に扔いて NAGT の構成成分の 1 つである hAlg13p プレイは、本来のパートナーである hAlg14ベイトの他に、 4 種類の酵素 (hAlg7p、hAlg1p、hAlg2p 及び hAlg11p) ベイ トに対して弱くそして同程度に相互作用していた(図 3A)。こ れらの観察結果は、rER 膜上でNAGTがGPTに対してのみ ならず、MT複合体とも物理的に相互作用している可能性が 高いことを示唆している。興味深いことに、MT 複合体中の 1 つの酵素である hAlg1lp ベイトは、hAlg7p プレイと弱く相互 作用しており、これはGPTもまた、MT複合体と物理的に相 互作用している可能性があることを示唆している。

\section{D. 後期 DLO 生合成に働く糖転移酵素}

酵母と同様にヒトに抢いて、3 種類の MT と 3 種類の GT が、rER 膜の内腔側における全長サイズの DLO $\left(\mathrm{Glc}_{3} \mathrm{Man}_{9}\right.$ $\mathrm{GlcNAc}_{2}$-PP-ドリコール)の後期生合成に関与している。これ らの糖転移酵素は、複数回膜貫通タンパク質であり、供与体 基質として rER 内に存在するドリコールリン酸糖を利用する ため (3 種類の MT はドリコールリン酸マンノースを、3 種類 の GTはドリコールリン酸グルコースを利用)、触媒ドメイン をrER 内腔に向けている。

膜配向性に関する解析の結果、全長サイズの DLO(Glc $\mathrm{CMan}_{9} \mathrm{GlcNAc}_{2}$-PP-ドリコール) の後期生合成に働く 6 種類の糖転移酵素べイトの $\mathrm{N}$ - 末端は、すべて細胞質に局在 化していることが示された (図 3B において、各ベイトの陽性 コントロールプレイである pAI-Alg5 との二重形質転換株が、 両選択培地上で増殖可能であったことに注目)。これらの観察 結果は、以前に報告されたこれらの酵素に関する膜配向性性 の予測と完全に一致していた (21)。したがって、これらの酵素 に関して、pBT-Nに基づいたべイトコンストラクトがさらな る物理的相互作用の解析に使用された (図 3B)。

D-1.hAlg3p、hAlg9p 及びhAlg12p は第 2 の MT 複合体を 形成する

後期 DLO 集合に働く 3 種類のマンノース転移酵素 (hAlg3p、hAlg9p 及び hAlg12p) をべイトに使用した場合、hAlg3p プレイとの各二重形質転換株は、SD-LWH 培地上で増殖した 
LWH medium (Fig. 3B), indicating that they form a second MT complex (The first one consists of hAlg1p, hAlg2p, and hAlg11p). In addition, it might consist of at least 2:2:2 of each enzyme, because every bait also interacted with the prey of itself (Fig. 3B). Interestingly, only the hAlg9p bait interacted with all three preys (Fig. 3B). The Alg9p catalyzes two steps of four reactions for mannose addition in late DLO biosynthesis (22), suggesting its central role in the complex.

\section{D-2. hAlg6p, hAlg8p, and hAlg10p Form a GT Complex}

In analyses with three glucosyltransferases (hAlg6p, $\mathrm{hAlg} 8 \mathrm{p}$, and hAlg10p) involved in late DLO assembly as baits, all co-transformants with each prey grew on SD-LWH medium (Fig. 3B). These observations indicate a closely related relationship among the three GTs, suggesting that this GT complex is firmer than the second MT complex.

\section{D-3. Physical Interaction between the Second MT Complex and the GT Complex}

Interestingly, each GT bait tightly interacted with the hAlg3p mannosyltransferase prey, a component of the second MT complex (Fig. 3B). Moreover, hAlg9p and hAlg12p baits weakly interacted with hAlg8p and hAlg10 preys, respectively (Fig. 3B). This evidence suggests that the GT complex should physically associate with the second MT complex to form one supra-complex composed of all enzymes involved in late DLO biosynthesis.

\section{E. Conclusion}

\section{E-1. The Significance of Complexes in DLO Biosynthesis}

It has been demonstrated that biosynthesis of DLO is essential for maintaining fundamental functions of eukaryotic cells, such as the cell cycle and signaling (23-25). In addition, DLO synthesis is well known to be closely related to the unfolded protein response (UPR). As soon as cellular proteins suffer from physical or chemical stress, the UPR is triggered in rER. In the UPR, ER-associated degradation (ERAD) is quickly induced in order to exclude proteins severely damaged (26), whereas DLO biosynthesis is accelerated in order to refold again and repair mildly damaged proteins (27).

For immediate performance of a series of enzymatic reactions in the UPR, related enzymes should be as cooperative and efficient as possible, and reversibly controlled. One way to achieve such enzymatic conduct is to assemble related enzymes into a complex. With an enzymatic complex system, against one substrate, several enzymes are accessible and capable of acting reciprocally in an extremely short time period. In addition, integrative regulation of several catalytic reactions is able to be easily carried out by forming/deforming a complex or separating certain enzymes from a complex.

\section{E-2. The DLO Assembly Process Possesses Two Potential Supra-Complexes}

Considering that fourteen enzymatic reactions catalyzed
(図 3B)。このことは、それらが第 2 の MT 複合体を形成して いることを示している(第1の MT 複合体は hAlglp、hAlg2p 及び hAlg11p からなる)。さらにそれは少なくとも 2:2:2 の各 酵素から構成されている可能性がある。というのは、すべて のベイトはまた自身のプレイとも相互作用したからである(図 3B)。興味深いことに、hAlg9p ベイトのみが3つ全てのプレ イと相互作用していた (図 3B)。Alg9p は、後期 DLO 生合成 における 4 段階のマンノース付加反応のうちの 2 段階を触媒 しており(22)、この複合体における中心的な役割が示唆される。 D-2. hAlg6p、hAlg8p 及びhAlg10p は GT 複合体を形成す る

後期 DLO 集合に関連する 3 種類のグルコース転移酵素 (hAlg6p、hAlg8p 及びhAlg10p) をべイトに用いた解析におい て、各プレイとの二重形質転換株は、すべて SD-LWH 培地上 で増殖した(図 3B)。これらの観察結果は、3 種類の GT 間の 密接に関連付けられた連携を示して㧍り、GT複合体が第 2 の MT 複合体よりも強固であることを示唆している。

D-3. 第 2 の MT 複合体と GT 複合体の間の物理的相互作用

興味深いことに、各 GT ベイトは、第 2 の MT 複合体の 構成成分の 1 つである hAlg3p マンノース転移酵素プレイと密 接に相互作用していた (図 3B)。さらに、hAlg9p 及び hAlg12p のベイトは、それぞれ hAlg8p 及びhAlg10 のプレイと弱く 相互作用していた (図 3B)。この証拠は、GT 複合体が第 2 の MT 複合体と物理的に会合し、DLO 生合成後期に関連する全 ての酵素から構成される 1 つの超複合体を形成している可能 性を示唆している。

\section{E. まとめ}

\section{E-1. DLO 生合成における複合体形成の意義}

DLO の生合成は、細胞周期、シグナル伝達といった真核 細胞の根本的な機能を維持するために必須であることが既に 実証されている (23-25)。さらにDLO 合成は、小胞体ストレ 又応答 (UPR)に密接に関連していることが良く知られている。 細胞のタンパク質が物理的あるいは化学的なストレスを被る とすぐに、rERに㧍いてUPRが誘発される。UPRでは、重 度の傷害を受けたタンパク質を除去するために小胞体関連分 解 (ERAD) が迅速に誘導され (26)、一方で DLO 生合成は、軽 度の傷害を受けたタンパク質を再度フォールドして修復する ために加速される $(27)$ 。

UPR 時の一連の酵素反応の迅速な実行のために、関連す る酵素は、可能な限り協調的で効率的であり、かつ可逆的に 制御されなければならないであろう。このような酵素の挙動 を達成するための 1 つの方法は、関連する酵素を集めて $1 つ$ の複合体を形成することである。酵素による複合体システム を用いると、1つの基質に対して、極めて短い時間内に、複数 の酵素が接触可能であり、かつ相互に作用可能である。さらに、 幾つかの触媒反応の統合的な調節は、複合体の形成/脱形成 あるいは特定の酵素の複合体からの離脱によって容易に実行 可能である。

\section{E-2. DLO 集合過程は 2 つの潜在的な超複合体を有する}

DLO 生合成が 11 種類の糖転移酵素により触媒される 14 


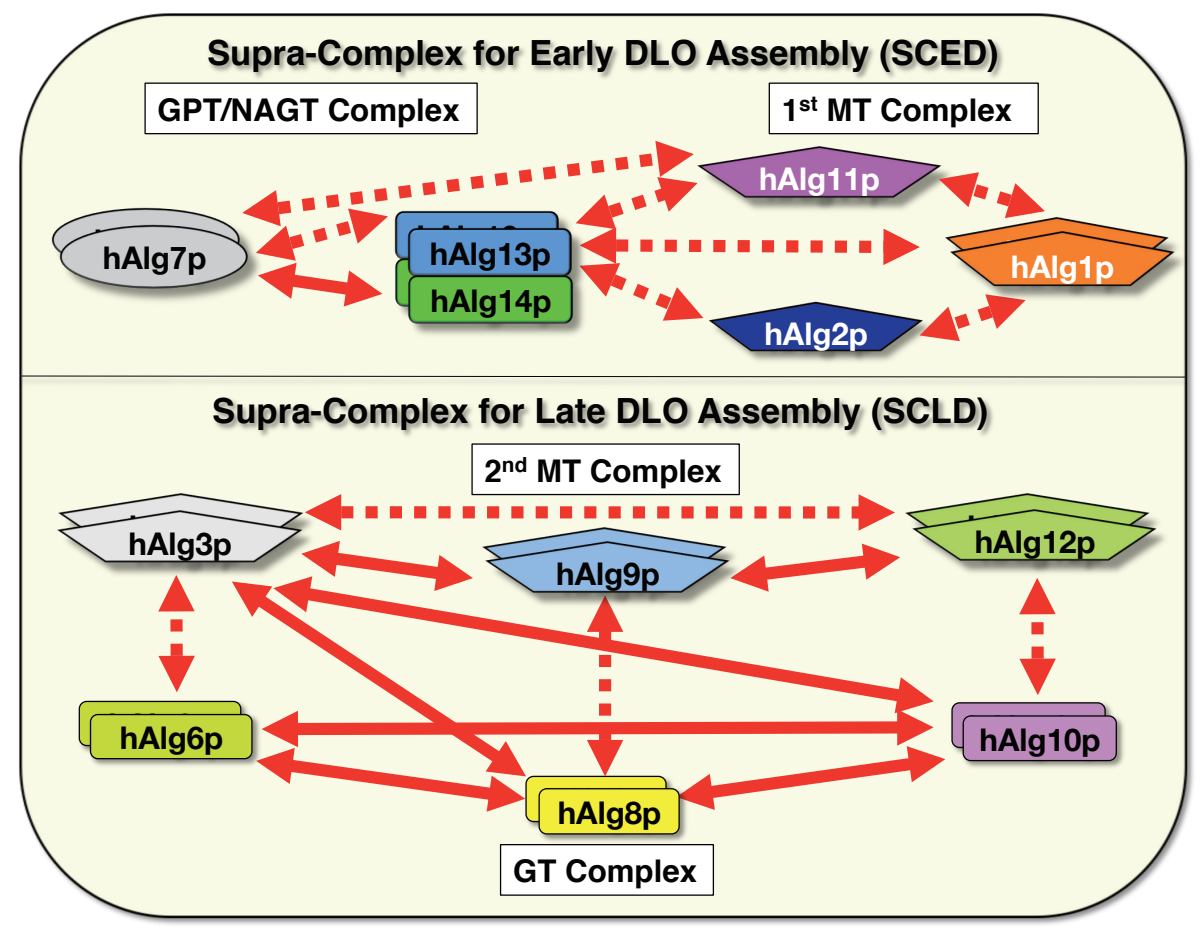

Fig. 4. The network model for human glycosyltransferases involved in DLO biosynthesis on the rER membrane. Arrows of solid and dotted lines indicate strong and weak interactions, respectively. Stacked objects of enzymes represent dimerization (or oligomerization).

by eleven glycosyltransferases constitute DLO biosynthesis, we speculated that there exists one or more complex system(s) for modulating DLO assembly on the rER membrane. In Fig. 4, all the results of our analyses of physical interactions of eleven human glycosyltransferases, revealed with the yeast splitubiquitin system, are summarized. Based on this model of an enzymatic network, we propose that two supra-complexes exist for regulation of the DLO biosynthetic pathway: one of that comprises an $\mathrm{hAlg} 7 \mathrm{p} / \mathrm{hAlg} 14 \mathrm{p} / \mathrm{hAlg} 13 \mathrm{p}$ complex and an $\mathrm{hAlg} 1 \mathrm{p} / \mathrm{hAlg} 2 \mathrm{p} / \mathrm{hAlg} 11 \mathrm{p}$ complex, and another that includes an hAlg3p/hAlg9p/hAlg12p complex and an hAlg6p/hAlg8p/ hAlg10p complex. As the former and the latter should regulate early and late DLO assembly, respectively, we advocate calling the former and the latter supra-complex for early DLO assembly (SCED) and supra-complex for late DLO assembly (SCLD), respectively.

\section{E-3. Possible Regulators in SCED}

As described in section C-3, hAlg13p, which associates with hAlg14p, also weakly but equally interacted with hAlg7p, hAlg1p, hAlg2p, and hAlg11p. This suggests that NAGT, composed of hAlg14p and hAlg13p, might be physically located centrally in SCED. Its central positioning proximal to all of the other four enzymes of SCED raises the possibility that it might serve as functional regulator in early DLO assembly. Notably, hAlg13p might play a key role in regulation of SCED, because it can assemble all enzymes involved in SCED, as well as supply hAlg14p localized on the
の酵素反応から成り立っていることを考えると、DLO 集合を 調整するための 1 つまたは複数の複合体システムが、rER 膜 上に存在していることが想定された。図 4 には、酵母 splitubiquitin システムを用いて私たちが明らかにした、11 種類 のヒト糖転移酵素に関する物理的相互作用の解析結果のす心゙ てが要約されている。この酵素のネットワークモデルに基づ いて、DLO 生合成経路を調節するために 2 つの超複合体が 存在することを、私たちは提案する。その 1 つは、 hAlg7p/ hAlg14p/hAlg13p 複合体と hAlg1p/hAlg2p/hAlg11p 複合体 から構成され、もう 1つは、hAlg3p/hAlg9p/hAlg12p 複合体 と hAlg6p/hAlg8p/hAlg10p 複合体を含んでいる。前者は前期、 後者は後期の DLO 集合をそれぞれ調節しているに違いないの で、私たちは、前者を前期 DLO 集合用超複合体 (SCED)、後 者を後期 DLO 集合用超複合体 (SCLD) とそれぞれ呼ぶことを 提唱する。

\section{E-3. SCED における可能な調節因子}

C -3 の項目中で述べた通り、hAlg14p と会合している hAlg13p はまた、hAlg7p、hAlg1p、hAlg2p 及びhAlg11p と も弱いながらも等しく相互作用していた。このことは、hAlg14p と hAlg13p からなる NAGT が物理的に SCED の中心に 位置づけられている可能性を示唆している。 SCED の他の 4 種 類すべての酵素に対して近位となるその中心的な位置取りは、 前期 DLO 集合においてそれが機能的な調節因子として働いて いる可能性を想起させる。特に、hAlg13p は、rER 膜に局在 する hAlg14p に細胞質に存在する UDP-GlcNAcを供給すると 同時に、SCED に関与するすべての酵素を集合可能なことから、 
rER membrane with UDP-GlcNAc present in the cytoplasm. As discussed in section E-1, the behavior of hAlg13p is considered to be suitable for regulating the rapid formation/ deformation of SCED. Indeed, we have also demonstrated that the C-terminus of yeast $\mathrm{Alg} 13 \mathrm{p}$ is important for both targeting for proteasomal degradation (28) and interacting with yeast Alg14p (29).

In contrast, hAlg14p interacted with none of the three MTs, though its physical interaction with hAlg13p and hAlg7p was strong (Fig. 3A), suggesting that SCED might be transiently formed via hAlg13p in the physiological environment.

As an alternative regulatory mechanism of SCED, feedback regulation of GPT by an MT complex may exist, because we detected a weak interaction between hAlg11p bait and hAlg7p prey (Fig. 3A). It is noteworthy that only hAlg $11 \mathrm{p}$, which acts in the final two steps of early DLO assembly, out of three MTs was proximal to hAlg7p that initiates DLO synthesis. It has been demonstrated that GlcNAc2-PP-dolichol, a product by NAGT, competitively inhibits GPT activity in chicks' microsomes (30). To address whether a similar regulatory mechanism by hAlg11p exists, investigation of the enzyme kinetics should be performed.

\section{E-4. Possible regulator in SCLD}

In contrast to SCED, it seems that SCLD is stably maintained on the rER membrane, because there were more interactions detected by the split-ubiquitin system in SCLD than in SCED, and each interaction also tended to be relatively strong. In section D-3, we pointed out that all glycosyltransferases in SCLD interacted with hAlg3p. This observation raises the possibility that $\mathrm{hAlg} 3 \mathrm{p}$ serves not only as an initiator, but also as a regulator of late DLO assembly. If $\mathrm{hAlg} 3 \mathrm{p}$ in SCLD monitors each step during late DLO biosynthesis, quite efficient and accurate regulation might be accomplished.

\section{E-5. Other Possible Regulator(s) in SCED and SCLD}

Probably SCED and/or SCLD include enzymes (or proteins) other than the glycosyltransferases examined above as components. In the human DLO assembly pathway, a variety of enzymes (or proteins) such as the dolichol-PMan synthase (DPMS) complex, which consists of hDPM1, hDPM2, and hDPM3, the proteins dolichol-P-Glc synthase, hRft1 protein, hMPDU1 protein, dolichol kinase, and dolichyl pyrophosphate phosphatase are indirectly involved. In particular, hRft1 protein could serve as a bridge between SCED and SCLD. In addition, the DPMS complex and hMPDU1 protein are also involved in both the biosynthesis of glycosylphosphatidylinositol (GPI) anchor and the $O$-mannosylation pathway, which are present on the luminal side of the rER membrane, as well as in DLO biosynthesis, in order to supply dolichol-P-Man as a donor substrate. Thus,
SCED の調節において鍵となる役割を果たしている可能性が ある。E-1の項目で論じた通り、hAlg13p の挙動は、SCEDの 迅速な集合/脱集合を調節するのに適していると考えられる。 実際に私たちはまた、酵母 Alg13pのC- 末端が、プロテアソー 厶分解への標的化 (28) 及び酵母 Alg14p との相互作用 (29) の両 方にとって重要であることも既に実証している。

予想に反して、hAlg14p は、hAlg13p やhAlg7p との物理 的相互作用は強かったものの、3 種類の MTのどれとも相互 作用しなかった(図 3A)。これは、生理的環境下でSCED は

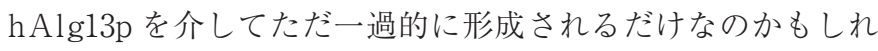
ないことを示唆している。

SCED の別の調節機構として、MT複合体による GPT の フィードバック調節が存在するかもしれない。なぜならば私 たちは、hAlg11pべイトと hAlg7 プレイ間の弱い相互作用 を検出したからである(図 $3 \mathrm{~A}$ )。3 種類の MTのうちで、前 期 DLO 集合の最終 2 段階に働くhAlg11pのみが DLO 合成を 開始する hAlg7p に対して近位であったことは注目に值する。 NAGT による生成産物である GlcNAC2-PP-ドリコールは競合 的に GPT 酵素活性を阻害することが、ヒヨコのミクロソーム を用いて既に実証されている (30)。hAlg11pによる同様な調節 機構が存在するかどうかに取り組むためには、酵素反応論の 調査が実行されなければならない。

\section{E-4. SCLD における可能な調節因子}

SCED とは対照的に、SCLD はrER 膜上で比較的安定に 維持されているように見える。というのは、split-ubiquitin シ ステムにより検出された相互作用は、SCED 中よりも SCDL 中の方が多く存在し、また各相互作用も比較的強い傾向にあっ たからである。D-3 の項目で私たちは、SCLD 中の糖転移酵素 すべてが hAlg3p と相互作用していることを指摘した。この 観察結果は、hAlg3p が後期 DLO 集合の開始因子としてのみ ならず、調節因子としても働いている可能性を提起している。 仮に SCLD 中の hAlg3p が後期 DLO 集合の期間に各段階を監 視しているとすれば、極めて効率的で正確な調節が達成され るであろう。

\section{E-5. SCED 及び DCLD における他の可能な調節因子}

おそらくSCED またはSCLDは、上で調べられた糖転 移酵素以外の酵素 (あるいは夕ンパク質) を構成成分として 含んでいるであろう。ヒトのDLO 集合経路には、hDPM1、 hDPM2 及びhDPM3 からなるドリコールリン酸マンノース合 成酵素 (DPMS) 複合体、ドリコールリン酸グルコース合成酵素、 hRft1 タンパク質、hMPDU1 タンパク質、ドリコールキナー ゼ及びドリコールピロリン酸ホスファターゼといった酵素 (あ るいはタンパク質) が、間接的に関与している。特に hRftl タ ンパク質は、SCED と SCLD の間の仲立ちとして機能してい る可能性がある。加えて、DPMS 複合体と hMPDU1 タンパク 質は、rER膜の内腔側に存在するグリコシルホスファチジル イノシトール (GPI) アンカー生合成とO-マンノシル化経路の 両方にも DLO 生合成と同様に関与しており、供与体基質とし 
more extensive analyses of physical interactions should be applied to rER resident enzymes related to the three types of glycosylation pathway to elucidate the regulatory mechanisms in glycan biosynthesis that occur in the rER. Screening for unknown physical interactions among these enzymes with the yeast split-ubiquitin system is in progress and has already identified several interesting ones (our unpublished observations).

\section{E-6. Perspectives}

In section $\mathrm{A}$, we mentioned the human hereditary disease CDG-I. Any defect in human glycosyltransferase activities involved in the DLO biosynthetic pathway can lead to CDG-I. We previously identified the HMT-1 gene, orthologous to the yeast $A L G 1$ (31), which encodes human MT-I (32). Since then, it has been demonstrated by several groups that dysfunction of HMT-1 results in CDG-Ik (3336). Of seven substitutional mutations reported to drastically decrease MT-I activity, S150R and G145D mutations are notable, because Ser ${ }^{150}$ and Gly ${ }^{145}$ residues of human MT-I are neither conserved nor located within a conserved domain. If these substitutions do not severely impair the substrate recognition domain, the transmembrane domain, or the overall structure and stability of the enzyme, they might impair a local domain crucial for physical interactions with itself or other enzymes. Our analyses with the yeast split-ubiquitin system will help to elucidate the effects of such mutations where the pathogenic nature remains to be explained.

Depending on the necessity of $N$-glycans or $\mathrm{N}$-glycoproteins, eukaryotic organisms appear to have different demands for DLO biosynthesis (37). We have also performed similar analyses for the yeast glycosyltransferases involved in DLO assembly. Yeast mutants defective in DLO assembly have been reported to have increased sensitivities toward antifungal drugs (38). In comparison between human and yeast enzymatic networks, there exist differences in the intensity of several physical interactions (our unpublished observations). By focusing on such differences and further analyzing them in detail, such as defining the domains necessary for interaction and determining their conformation, we can develop basic antifungal agents that can specifically inhibit certain fungal glycosyltransferase activities on the basis of blocking optional physical interactions between two membrane proteins (39).

\section{Acknowledgments}

We thank Dr. Kazuya Kabayama (Institute of Glycoscience, Tokai University) for giving us the opportunity of writing this review. We also thank Dr. Hiroyuki Tachikawa (Graduate School of Agricultural and Life Science, University of Tokyo) for supporting this work in various aspects. This work was partially supported by two subsidies for activating educational institutions of Tokai University.
てのドリコールリン酸マンノースを供給している。したがっ て、rER で生じている糖鎖生合成における調節機構を解明す るためには、物理的相互作用に関するより一層広範な解析が、 3 種類のグリコシル化経路に関連する rER 局在酵素に対して 適用されるべきであろう。酵母 split-ubiquitin システムを用い たそれら酵素間の未知の物理的相互作用に関するスクリーニ ングは現在進行中であり、既に幾つかの興味深い相互作用を 同定している (私たちの未公表の観察結果による)。

E-6. 展 望

A の項目で私たちは、ヒト遺伝病である CDG-I 型につい て触れた。DLO生合成経路に関連するヒト糖転移酵素活性 におけるいかなる欠陷も CDG-I を導きうる。私たちは、ヒト MT-I をコードし、酵母 ALG1(31) の相同遺伝子である HMT-1 遺伝子を以前に同定した (32)。それ以来、幾つかのグループ により HMT-1 の機能不全は、CDG-Ik を生じることが実証さ れている(33-36)。MT-I活性を劇的に減少させることが報告 されている 7 つの置換変異の中で、 S150R 変異及び G145D 変 異は注目に值する。というのは、ヒトMT-I の $\operatorname{Ser}^{150}$ 残基及び $\mathrm{Gly}^{145}$ 残基は、保存されてもおらず、保存性のドメイン内にも 位置していないからである。仮にこれらの置換が、酵素の基 質認識ドメイン、膜貫通ドメインあるいは全体の構造及び安 定性を重度に障害しないとすれば、それらは自身あるいは他 の酵素との物理的相互作用に重要な局所的なドメインを障害 している可能性がある。酵母 split-ubiquitin システムを利用し た私たちの解析は、病因となる本質が未だ充分説明されてい ない、このような変異の効果を解明するのに役に立つであろ う。

$N$-グリカンまたは $N$ - 型糖タンパク質の必要性に応じて、 真核生物は、DLO 生合成に関する要求性が異なっていると考 えられる (37)。私たちはまた、DLO 集合に関連する酵母の糖 転移酵素に関しても同様の解析を行ってきた。DLO 集合に欠 陥を有する酵母変異株は、抗真菌剂に対する感受性を増大さ せていることが報告されている $(38)$ 。ヒトと酵母の間で、酵素 ネットワークを比較すると、幾つかの物理的相互作用の強度 に差異が存在している(私たちの未公表の観察結果による)。 今後これらの違いに着目し、相互作用に必要なドメインの限 定やその高次構造の決定などのより詳細な解析をさらに行う ことによって、2つの膜タンパク質間の任意の物理的相互作用 の封鎖に基ついて特定の真菌糖転移酵素活性を特異的に阻害 可能な抗真菌剤の開発が可能になるであろう (39)。

\section{謝辞}

本稿の執筆の機会を与えていただいた東海大学糖鎖科学 研究所の樺山一哉博士に感謝いたします。また、この研究を 様々な局面で支えていただいた東京大学大学院農学生命科学 研究科の舘川宏之博士にも感謝いたします。なお本研究は、 遂行にあたり、二回の東海大学学部等研究教育補助金のご援 助を頂きました。 


\section{References}

1. Cantagrel, V., and Lefeber, D. J. (2011) J. Inherit. Metab. Dis. 34, 859-867.

2. Haeuptle, M., and Henner, T. (2009) Hum. Mutat. 30, 1628-1641.

3. Johnsson, N., and Varshavsky, A. (1994) Proc. Natl. Acad. Sci. USA 91, 10340-10344.

4. Stagljar, I., Korostensky, C., Johnsson, N., and te Heesen, S. (1998) Proc. Natl. Acad. Sci. USA 95, 5187-5192.

5. Fetchko, M., and Stagljar, I. (2004) Methods 32, 349-362.

6. Thaminy, S., Miller, J., and Stagljar, I. (2004) Methods. Mol. Biol. 261, 297-312.

7. Dünnwald, M., Varshavsky, A., and Johnsson, N. (1999) Mol. Biol. Cell 10, 329-344.

8. Massaad, M. J., and Herscovics, A. (2001) J. Cell Sci. 114, 4629-4635.

9. Scheper, W., Thaminy, S., Kais, S., Stagljar, I., and Römisch, K. (2003) J. Biol. Chem. 278, 37998-38003.

10. Yan, A., and Lennarz, W. J. (2005) Proc. Natl. Acad. Sci. USA 102, 7121-7126.

11. Dan, N., Middleton, B., and Lehrman, M. A. (1996) J. Biol. Chem. 271, 30717-30724.

12. Averbeck, N., Keppler-Ross, S., and Dean, N. (2007) J. Biol. Chem. 282, 29081-29088.

13. Kämpf, M., Absmanner, B., Schwarz, M., and Lehle, L. (2009) J. Biol. Chem. 284, 11900-11912.

14. Absmanner, B., Schmeiser, V., Kämpf, M., and Lehle, L. (2010) Biochem. J. 426, 205-217.

15. Dan, N., and Lehrman, M. A. (1997) J. Biol. Chem. 272,14214-14219.

16 Noffz, C., Keppler-Ross, S., and Dean, N. (2009) Glycobiology 19, 472-478.

17. Lu, J., Takahashi, T., Ohoka, A., Nakajima, K. I., Hashimoto, R., Miura, N., Tachikawa, H., and Gao, X. -D. (2012) Glycobiology 22, 504516.

18. Gao, X. -D., Tachikawa, H., Sato, T., Jigami, Y., and Dean, N. (2005) J. Biol. Chem. 280, 36254-36262.

19. Bickel, T., Lehle, L., Schwarz, M., Aebi, M., and Jakob, C. A. (2005) J. Biol. Chem. 280, 34500-34506.

20. Gao, X. -D., Nishikawa, A., and Dean, N. (2004) Glycobiology 14, 559-570.

21. Oriol, R., Martinez-Duncker, I., Chantret, I., Mollicone, R., and Codogno, P. (2002) Mol. Biol. Evol. 19, $1451-1463$.

22. Frank, C. G., and Aebi, M. (2005) Glycobiology 15, 1156-1163.

23. Benton, B. K., Plump, S. D., Roos, J., Lennarz, W. J., and Cross, F R. (1996) Curr. Genet. 29, 106-113.

24. Kukuruzinska, M. A., and Lennon-Hopkins, K. (1999) Biochim. Biophys. Acta 1426, 359-372.

25. Mendelsohn, R. D., Helmerhorst, E. J., Cipollo, J. F., Kukuruzinska, M. A. (2005) Biochim. Biophys. Acta 1723, 33-44.

26. Bagola, K., Mehnert, M., Jarosch, E., and Sommer, T. (2011) Biochim. Biophys. Acta 1808, 925-936.

27. Shang, J., Korner, C., Freeze, H., and Lehrman, M. A. (2002) Glycobiology 12, 307-317.

28. Averbeck, N., Gao, X. -D., Nishimura, S., and Dean, N. (2008) Mol. Biol. Cell 19, 2169-2178.

29. Gao, X. -D., Moriyama, S., Miura, N., Dean, N., and Nishimura, S. (2008) J. Biol. Chem. 283, 32534-32541.

30. Kean, E. L., Wei, Z., Anderson, V. E., Zhang, N., and Sayre, L. M. (1999) J. Biol. Chem. 274, 34072-34082.

31. Couto, J. R., Huffaker, T. C., and Robbins, P. W. (1984) J. Biol. Chem. 259, 378-382.

32. Takahashi, T., Honda, R., and Nishikawa, Y. (2000) Glycobiology 10, 321-327.

33. Schwarz, M., Thiel, C., Lubbehusen, J., Dorland, B., de Koning, T., von Figura, K., Lehle, L., and Korner, C. (2004) Am. J. Hum. Genet. 74, 472-481.

34. Kranz, C., Denecke, J., Lehle, L., Sohlbach, K., Jeske, S., Meinhardt, F., Rossi, R., Gudowius, S., and Marquardt, T. (2004) Am. J. Hum. Genet. 74, 545-551.

35. Grubenmann, C. E., Frank, C. G., Hulsmeier, A. J., Schollen, E., Matthijs, G., Mayatepek, E., Berger, E. G., Aebi, M., and Hennet, T. (2004) Hum. Mol. Genet. 13, 535-542.

36. Dupre, T., Vuillaumier-Barrot, S., Chantret, I., Yaye, H. S., Le Bizec, C., Afenjar, A., Altuzarra, C., Barnerias, C., Burglen, L., de Lonlay, P., Feillet, F., Napuri, S., Seta, N., and Moore, S. E. H. (2010) J. Med. Genet. 47, 729-735.

37. Samuelson, J., Banerjee, S. Magnell, P., Cul, J., Kelleher, D. J., Gilmore, R., and Robbins P. W. (2005) Proc. Natl. Acad. Sci. USA 102, 1548-1553.

38. Juchimiuk, M., Pasikowska, M., Zatorska, E., Laudy, A. E., Smoleńska-Sym, G., and Palamarczyk, G. (2010) Yeast $27,637-645$.

39. Fetchko, M., Auerbach, D., and Stagljar, I. (2003) BioDrugs 17, 413-424. 


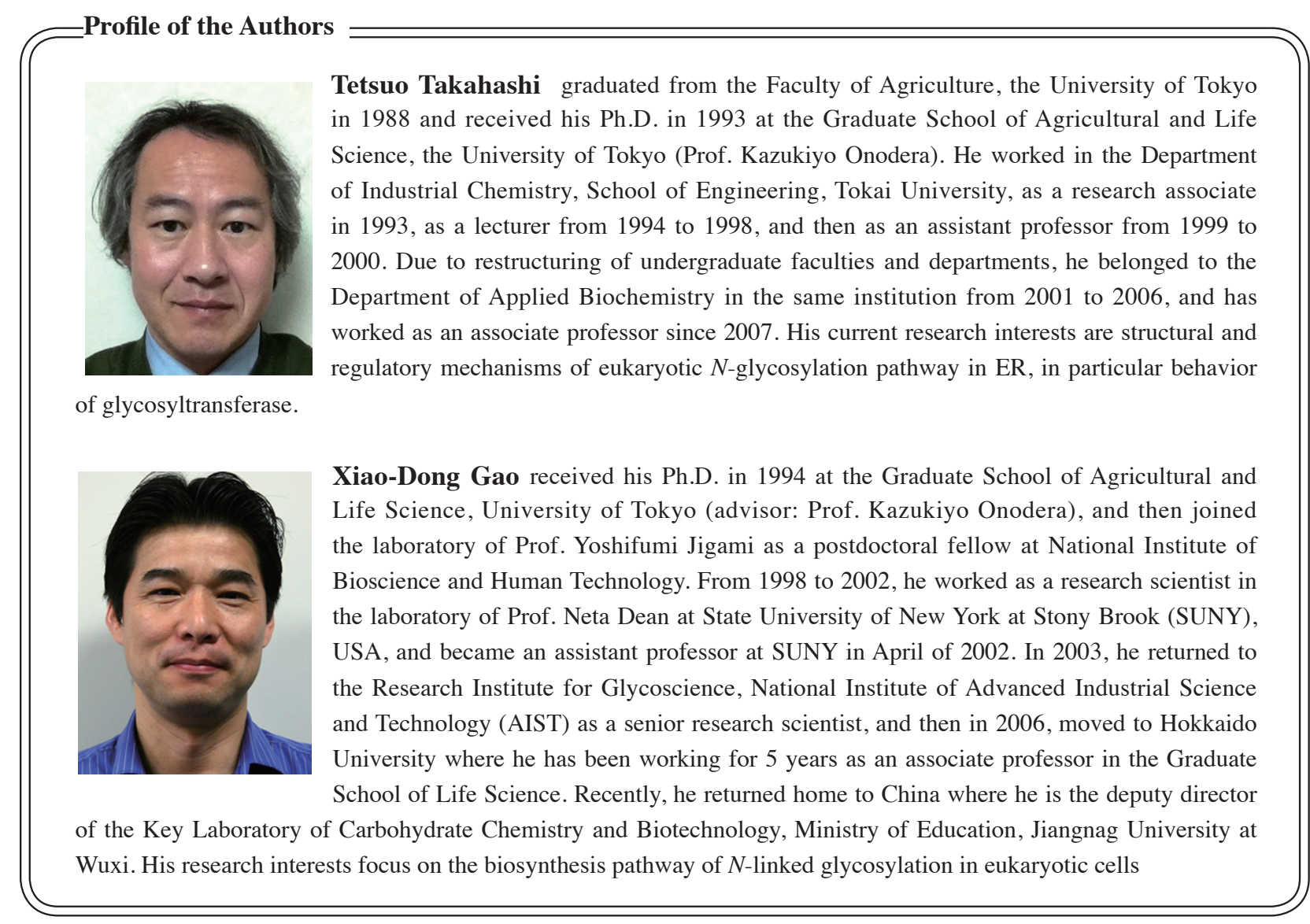

